\title{
Susceptibility characterization of residual Brazilian populations of Triatoma infestans Klug, 1834 (Hemiptera: Reduviidae) to deltamethrin pyrethroid
}

\author{
Grasielle Caldas D 'avila Pessoa ${ }^{[1]}$, Aline Cristine Luiz Rosa ${ }^{[1]}$, Cleonara Bedin ${ }^{[2]}$, \\ Tânia Wilhelms ${ }^{[2]}$, Fernanda de Mello ${ }^{[2]}$, Helder Silveira Coutinho ${ }^{[3]}$, \\ Eduardo Oyama Lins Fonseca ${ }^{[3]}$, Roberto Fonseca dos Santos ${ }^{[3]}$ \\ and Liléia Diotaiuti ${ }^{[1]}$
}

[1]. Laboratório de Triatomíneos e Epidemiologia da Doença de Chagas, Centro de Pesquisas René Rachou, Fundação Oswaldo Cruz, Belo Horizonte, Minas Gerais, Brasil. [2]. Laboratório Central de Saúde Pública do Rio Grande do Sul, Instituto de Pesquisas Biológicas, Secretaria de Saúde do Rio Grande do Sul, Porto Alegre, Rio Grande do Sul, Brasil. [3]. Laboratório Central de Saúde Pública da Bahia, Diretoria de Vigilância Epidemiológica, Secretaria de Saúde da Bahia, Salvador, Bahia, Brasil.

\begin{abstract}
Introduction: Despite years of efforts towards the elimination of Triatoma infestans in Brazil, residual foci still persist in some areas of the States of Bahia and Rio Grande do Sul. The persistence of these T. infestans populations in the country has two different origins of equal concern: operational failures or insecticide resistance. Thus, the objective of this study was to characterize the susceptibility profile of the residual Brazilian populations of T. infestans to deltamethrin. Methods: The susceptibility reference lineage was derived from Cipein/Argentina. The populations studied were manually collected using a dislodging agent in peridomiciles in the States of Bahia (Novo Horizonte) and of Rio Grande do Sul (Santa Rosa and Doutor Maurício Cardoso). Serial dilutions of deltamethrin were prepared and applied at the dorsal abdomen of first instar nymphs. The control group received only pure acetone. Mortality was evaluated after $72 \mathrm{~h}$. Qualitative tests assessed the mortality of a diagnostic dose of $1 \mathrm{xLD}_{99}(2.76 \mathrm{ng}$ a.i./nymph) determined for the susceptibility reference lineage. Results: The susceptibility profile characterization of the $T$. infestans populations revealed an $\mathrm{RR}_{50}$ ranging from 1.73 to 3.26. The mortality percentage in response to a diagnostic dose was $100 \%$. The results obtained in the quantitative and qualitative assays corresponded for all populations. Conclusions: The results of this study indicate that the persistence of residual foci of $T$. infestans in Bahia and Rio Grande do Sul is not related to insecticide resistance but may be associated with operational failures. In Rio Grande do Sul, we must consider the possibility of continuous reinfestation by Argentinian individuals, which justifies active and efficient epidemiological surveillance.
\end{abstract}

Keywords: Triatominae. Triatoma infestans. Insecticide resistance. Deltamethrin.

\section{INTRODUCTION}

Triatoma infestans is not a native species of Brazil and therefore must be eradicated. T. infestans was most likely introduced to Brazil from the south, reaching São Paulo and other southern states in the late $18^{\text {th }}$ century, during the expansion of coffee cultivation in Brazil. The patterns of human migration and rural settlement and associated ecological changes appear to have favored the triatomine, allowing it to colonize poor rural dwellings over a wide area ${ }^{(1)}$. The first prophylactic

Corresponding author: Dra. Liléia Diotaiuti. Laboratório de Triatomíneos e Epidemiologia da Doença de Chagas/CPqRR/FIOCRUZ. Av. Augusto de Lima 1715, Barro Preto, 30190-002 Belo Horizonte, MG, Brasil.

Phone: 5531 3349-7762; Fax: 5531 3295-3115

e-mail: diotaiuti@cpqrr.fiocruz.br

Received 12 January 2015

Accepted 11 March 2015 attempts at triatomine control in Brazil date to the 1920s, but only with the advent of synthetic insecticides, particularly pyrethroids, was progress in vector control achieved. In 1977, control actions were systematized and structured in national programs [Brazilian Chagas Disease Programme (BCDP)] in which priority was given to the control of the vector across all endemic areas. Most of the efforts to combat $T$. infestans have focused on regions with a predominance of species with greater ecological valence, such as Panstrongylus megistus, Triatoma brasiliensis, Triatoma pseudomaculata, and Triatoma sordida(2).

The initial dispersion of Triatoma infestans in Brazil $(1975 / 1983)$ corresponded to 711 counties in 12 states. In 1983, when preliminary entomological evaluations were concluded, 162,136 specimens of $T$. infestans were captured, representing $13.5 \%$ of all triatomines captured, regardless of species. In 1997, the dispersion corresponded to 105 counties in 7 states, including new counties that were created since 1983. A total of 1,080 specimens of 
Triatoma infestans specimens were captured between 1983 and 1997 , corresponding to only $0.5 \%$ of all specimens collected. Thus, there was a $99.3 \%$ reduction in the number of T. infestans specimens captured between 1983 and $1997^{(3)}$.

In the State of Minas Gerais at the beginning of the 1980s, Ministry of Health data indicated that $T$. infestans represented $64.6 \%$ of triatomines captured by BCDP, followed by $T$. sordida and $P$. megistus. In 1989, after nine years of spraying, there was a $68 \%$ reduction in the number of $T$. infestans captured and an increase in the number of T. sordida, followed by P. megistus ${ }^{(4)}$. In that same period, São Paulo achieved a virtual elimination of T. infestans and vector transmission associated with this species ${ }^{(1)}$.

In 1991, Argentina, Bolivia, Brazil, Paraguay and Uruguay, supported by the Pan American Health Organization (PAHO), created an intergovernmental commission known as the Southern Cone Initiative to, among other objectives, eradicate house infestation by T. infestans ${ }^{(5)}$. Between 1980 and 2000, there was a progressive elimination of $T$. infestans in several Brazilian states, in addition to a significant reduction in triatomine intradomicile infestation rates across the country. Thus, in 2006, Brazil received the International Elimination of Transmission of Chagas' Disease Certificate from $\mathrm{PAHO}^{(6)}$. However, for unknown reasons, residual foci of $T$. infestans remain in Bahia and Rio Grande do Sul.

The persistence of triatomine populations in spite of control activities may be related to two distinct scenarios that are equally worrying. The first scenario, in which operational failures complicate vector control, indicates an urgent need for improved training of managers and public health officials. The second scenario, in which ineffective control is due to intrinsic characteristics of triatomines that confer insecticide resistance $^{(7)(8)(9)(10)(11)(12)(13)(14)(15)(16)(17)(18)(19)(20)(21)}$, requires a better understanding of the biological, biochemical, molecular and behavioral aspects of these characteristics. In Rio Grande do Sul, the possibility of reinfestation by specimens from Argentinian areas is also relevant.

Thus, to better understand the factors that complicate the control of T. infestans populations in Brazil, this study characterized the toxicological profile of these populations to deltamethrin pyrethroid in six different municipalities using laboratory bioassays.

\section{METHODS}

The populations studied were manually collected using a dislodging agent from peridomiciles in the States of Bahia (Novo Horizonte: $12^{\circ} 48^{\prime} 28^{\prime \prime} \mathrm{S} 42^{\circ} 10^{\prime} 04^{\prime \prime} \mathrm{O}$ ) and Rio Grande do Sul (Santa Rosa: $27^{\circ} 52^{\prime} 15^{\prime \prime} \mathrm{S} 54^{\circ} 28^{\prime} 51^{\prime \prime} \mathrm{O}$ and Doutor Maurício Cardoso: $27^{\circ} 30^{\prime} 21^{\prime \prime} \mathrm{S} 54^{\circ} 21^{\prime} 39^{\prime}$ ' O), in which the Chagas Disease Control Program ${ }^{(22)}$ conducted continuous and systematic applications of insecticides with residual action in the previous 30 years (Table $\mathbf{1}$ ).

A susceptibility reference lineage (SRL) was used; breeding of the SRL began in 2005 at the insectary of the Laboratório de Triatomíneos e Epidemiologia da Doença de Chagas (LATEC) from Centro de Investigaciones de Plagas e Insecticidas (CIPEIN), in accordance with the criteria adopted by $\mathrm{PAHO}^{(23)}$.

Bioassays were performed according the methods of Pessoa $^{(24)}$ and World Health Organization (WHO) ${ }^{(25)}$. Serial dilutions $(0.1-8.0 \mathrm{ng} / \mu \mathrm{L})$ of deltamethrin $(98.2 \%$ purity, Bayer: São Paulo, SP - Brazil) were prepared and applied to the abdomen of first instar nymphs from the F1 generation (five days of age, fasting weight $1.2 \pm 0.2 \mathrm{mg}$ ) using a Hamilton microsyringe $(0.5 \mu \mathrm{L}$ per insect). Acetone alone was applied to the insects in the control groups. At least six doses encompassing the lethal dose $50 \%\left(\mathrm{LD}_{50}\right)$ and producing between 10 and $90 \%$ mortality were administered. Three replicates of ten nymphs were conducted for each dose at different times. Mortality was recorded at $72 \mathrm{~h}$. The criterion for mortality was the inability of a nymph to walk out of a filter paper disc $7 \mathrm{~cm}$ in diameter.

The mortality data were analyzed using Basic Probit Analysis ${ }^{(26)}$ software to estimate the $\mathrm{LD}_{50}$ expressed in nanograms of active ingredient per treated nymph (a.i./nymph) and the slope. The 50\% resistance ratios $\left(R_{50}\right)$ were calculated by dividing the $L_{50}$ of each field population by that of the corresponding SRL. The susceptibility status classification was performed according to $\mathrm{PAHO}^{(23)}$.

After establishing the baseline susceptibility of the T. infestans reference population, 30 nymphs from each peridomestic population were subjected to a diagnostic dose of $1 \mathrm{xLD}_{99}(2.76 \mathrm{ng}$ a.i./nymph.) based on the SRL. The survival of at least two insects among three replicates was interpreted as a resistance indicator ${ }^{(25)}$.

TABLE 1 - Samples of the peridomestic populations of Triatoma sordida, geographical origin, capture site (ecotope), and the number of insects captured in each stage of development.

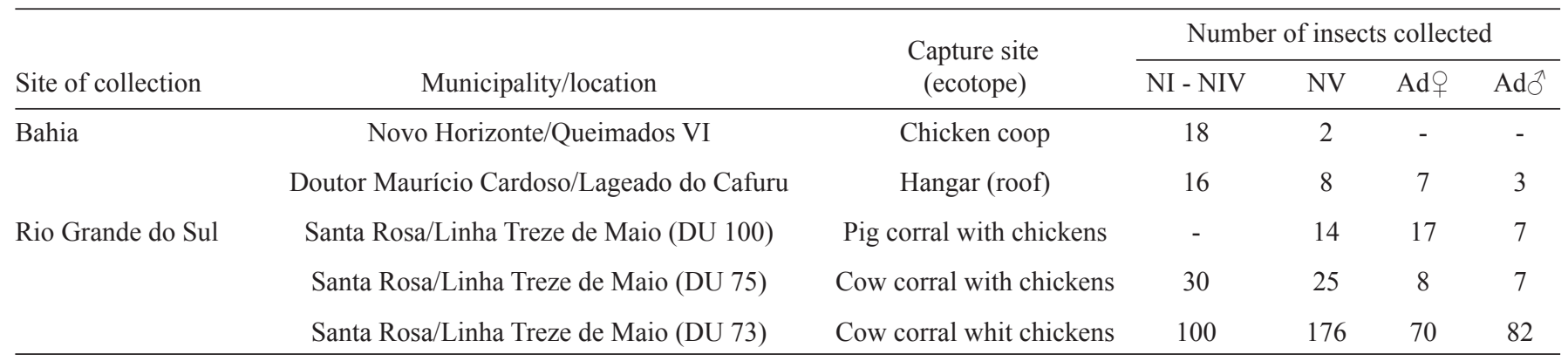

NI: First instar nymph; NIV: fourth instar nymph; NV: fifty instar nymph; N: nymphs; Ad: adults; $९$ : females; $\precsim$ : males. DU: domiciliary unit. 


\section{RESULTS}

The susceptibility reference lineage exhibited an $\mathrm{LD}_{50}$ of $0.415 \mathrm{ng}$ a.i./nymph treated. The susceptibility profile characterization of the T. infestans populations revealed $\mathrm{RR}_{50}$ values ranging from 1.73 to 3.26 . All populations presented slopes equal to or higher than the slope of the SRL, revealing a lower heterogeneity. The mortality percentage in response to a diagnostic dose in all populations was 100\% (Table 2).

\section{DISCUSSION}

In Southern Bolivia and Northern Argentina, the reinfestation of households treated with insecticides is a serious concern and occurs particularly rapidly in the region of Gran $\mathrm{Chaco}^{(26)(27)(28)}$, due to the high levels of insecticide resistance in domestic ${ }^{(29)(30)}$ and wild populations ${ }^{(31)(32)(33)}$, among other factors. The different pyrethroid susceptibility profiles observed in this area are associated with changes in one or more toxicokinetic/toxicodynamic processes during the insect-insecticide interaction, highlighting the changes in the chemical active penetration site, the increase in its enzymatic detoxification rate and mutations in the sodium channel ${ }^{(10)(13)(17)(20)(21)(32)}$.

Regarding Brazilian populations of T. infestans, Vassena et al. ${ }^{(7)}$ first characterized the susceptibility of a population from Rio Grande do Sul to deltamethrin $\left(R_{50} 7.0\right)$, betacypermethrin $\left(R_{50}\right.$ $0.92)$, betacyfluthrin $\left(R_{50} 3.6\right)$, lambdacyhalothrin $\left(R_{50} 1.75\right)$ and cypermethrin $\left(\mathrm{RR}_{50} 3.35\right)$. Laboratory bioassays identified resistance only to deltamethrin, which involves mixed-function oxidases. The authors associated this resistance with the intensive use of pyrethroids (deltamethrin and cypermethrin) for triatomine control after 1982, when Lindane was discouraged ${ }^{(33)(34)}$.

Sonoda et al. ${ }^{(15)}$ characterized the toxicological profile of the T. infestans populations originating from four municipalities subjected to successive spraying with pyrethroids in Rio Grande do Sul (Doutor Maurício Cardoso $R_{50} 0.72$, Guarani das Missões $\mathrm{RR}_{50} 0.57$, Mato Queimado $\mathrm{RR}_{50} 1.47$, and
Três de Maio $\mathrm{RR}_{50}$ 1.86). The studied populations had very low resistance ratios, indicating a lack of deltamethrin resistance. The populations studied by Vassena et al. ${ }^{(7)}$ and Sonoda et al. ${ }^{(15)}$ originated from different locations, which may explain the discrepancies in the results of these studies.

In this work, the results of quantitative bioassays of the Novo Horizonte population in Bahia indicated an $\mathrm{RR}_{50}$ of 1.74 . For the Rio Grande do Sul populations, the $\mathrm{RR}_{50}$ ranged from 1.73 to 3.26. In both cases, in accordance with the PAHO ${ }^{(23)}$, all populations presented $R R<5$ and were thus classified as susceptible to the insecticide evaluated. The qualitative tests demonstrated $100 \%$ mortality in all populations of $T$. infestans in response to the diagnostic dose, further confirming the susceptibility to deltamethrin ${ }^{(25)}$. Our results and those of Sonoda et al. ${ }^{(15)}$ demonstrate that the populations of $T$. infestans in the municipalities of Doutor Maurício Cardoso and Santa Rosa are susceptible.

The slope for all populations studied was equal to or greater than that for the SRL, suggesting a small degree of intrapopulational heterogeneity and a reduced possibility of change in the toxicological profile before the selection pressure with continued use of insecticides. This result may be related to the structuring of the triatominic populations as small groups with limited dispersal and reduced genetic flow, as observed in some Triatominae species. In addition, molecular studies have demonstrated that genetic diversity is significantly lower in chemically treated areas than in untreated areas, indicating active chemical pressure on populations ${ }^{(19)(35)(36)(37)}$.

Notably, the susceptibility profile observed for these populations of $T$. infestans in response to deltamethrin cannot be extended to other insecticides. The same triatomine population may present different susceptibility profiles to different chemical classes of insecticides ${ }^{(10)(12)(13)(20)(33)(37)(38)(39)}$ and to chemicals belonging to the same class ${ }^{(7)(10)(12)}$.

In addition, the different toxicological profiles of the two populations of T. infestans from Santa Rosa (Linha Treze de Maio), in which insects were collected in different households, suggest that the selection process for insecticide resistance can occur independently, even in neighboring houses ${ }^{(39)}{ }^{(40)}$. This study indicates the

TABLE 2 - The toxicity of topically applied deltamethrin on Triatoma infestans first instars of a susceptible reference lineage and peridomestic populations collected from States of Bahia and Rio Grande do Sul, Brazil.

\begin{tabular}{|c|c|c|c|c|}
\hline Population: municipality/location-State & $\begin{array}{c}\mathrm{LD}_{50} \\
(95 \% \mathrm{CI})\end{array}$ & $\mathrm{RR}_{50}$ & Slope & $\begin{array}{c}\text { Diagnostic dose } \\
\text { (\% mortality) }\end{array}$ \\
\hline CIPEIN (SRL) & $0,415(0,345-0,497)$ & - & $2,825+/-0,363$ & - \\
\hline Doutor Maurício Cardoso/Lageado do Cafuru - RS & $0,741(0,629-0,868)$ & 1.76 & $2,762+/-0,432$ & 100.0 \\
\hline Santa Rosa/Linha Treze de Maio (DU 100) - RS & $0,733(0,446-0,985)$ & 1.73 & $2,162+/-0,591$ & 100.0 \\
\hline Santa Rosa/Linha Treze de Maio (DU 73) - RS & $1,372(1,156-1,696)$ & 3.26 & $3,378+/-0,670$ & 100.0 \\
\hline
\end{tabular}

DU: domiciliary unit; $\mathrm{LD}_{50}: 50 \%$ lethal dose; $95 \% \mathrm{CI}$ : $95 \%$ confidence interval; $\mathrm{RR}_{50}: 50 \%$ resistance ratio; CIPEIN: Centro de Investigaciones de Plagas e Insecticidas; SRL: susceptible reference lineage; BA: State of Bahia; RS: State of Rio Grande do Sul. 
inadequacy of transposing results from one population to another, even for populations that are geographically close. Amelloti et al. ${ }^{(41)}$ demonstrated that a single female, when kept isolated throughout her life, has the potential to generate more resistant offspring when she is young and more susceptible offspring when she is older. This result indicates the complexity of genetic variability at the individual level and its potential impact in the population context. This variability emphasizes the need for caution when defining sample size in studies of resistance in triatomines to ensure that the sample is truly representative of the study population.

Thus, the results of this study indicate that the persistence of residual foci of $T$. infestans in Bahia and Rio Grande do Sul is not related to insecticide resistance but more likely to operational failures in vector control strategies, such as 1) a lack of insecticide efficiency due to poor-quality active ingredients and/or an inadequate formulation; 2) operational failures related to the lack of training of health agents ${ }^{(42)} ; 3$ ) environmental conditions, mainly within peridomiciles, that accelerate degradation of the insecticide ${ }^{(43)(44)}$; 4) an effect of peridomicile characteristics on the behavior of $T$. infestans; and 5) spraying cycle discontinuity due to administrative and budgetary concerns ${ }^{(45)(46)(47)}$. These factors, individually or in combination, expose the triatomine to sublethal doses that select for the least susceptible insects.

Finally, the artificial environment colonization capacity and the transmission potential of Trypanosoma cruzi by T. infestans emphasize the importance of systematic, continuous chemical control activities and guaranteed operational quality as well as health awareness activities. These activities should focus of the reorganization of household units to avoid refractory colonization by triatomines. The geographical proximity of Southern Brazil to Argentina and Bolivia allows T. infestans to flow between these regions, justifying active and efficient entomological and epidemiological surveillance to control the identified targets as early as possible.

\section{ACKNOWLEDGMENTS}

We are grateful to Bayer S.A. for providing the technical insecticide used.

\section{CONFLICT OF INTEREST}

The authors declare that there is no conflict of interest.

\section{FINANCIAL SUPPORT}

Financial support was provided by the Conselho Nacional de Desenvolvimento Científico e Tecnológico (CNPq), Centro de Pesquisas René Rachou (CPqRR), Fundação Oswaldo Cruz (FIOCRUZ), Secretaria de Vigilância em Saúde (SVS), Ministério da Saúde (MS) - Brazil - and World Health Organization (WHO).

\section{REFERENCES}

1. Dias JCP, Borges Dias R. Aspectos sociais, econômicos e culturais da doença de Chagas. Cien Cult 1979; 31:105-124.

2. Ministério da Saúde. Manual de Normas Técnicas da Campanha de Controle da doença de Chagas. Brasília: Superintendência de Campanhas de Saúde Pública; 1980.

3. Fundação Nacional de Saúde (FNS). Coordenação de Minas Gerais. Relatório Técnico. Belo Horizonte: FNS; 1995.

4. Silveira AC, Vinhaes MC. Elimination of vector-borne transmission of Chagas disease. Mem Inst Oswaldo Cruz 1999; 94:405-411.

5. Schofield CJ, Jannin J, Salvatella R. The future of Chagas disease control. Trends Parasitol 2006; 22:583-588.

6. Dias JCP. Doença de Chagas: sucessos e desafios. Cad Saude Publica 2006; 22:2020-2021.

7. Vassena CV, Picollo MI, Zerba EN. Insecticide resistance in Brazilian Triatoma infestans and Venezuelan Rhodnius prolixus. Med Vet Entomol 2000; 14:51-55.

8. Zerba EN, Picollo MI. Resistencia a insecticidas piretroides en Triatoma infestans. Buenos Aires, Argentina: Centro de Investigaciones de Plagas e Insecticidas (CIPEIN), Investigaciones Científicas y Técnicas de las Fuerzas Armadas (CIFETA) y Consejo Nacional de Investigaciones Científicas Y Técnicas (CONICET); 2002.

9. González-Audino P, Vassena C, Barrios S, Zerba EN, Picollo MI. Role of enhanced detoxication in a deltamethrin-resistant population of Triatoma infestans (Hemiptera, Reduviidae) from Argentina. Mem Inst Oswaldo Cruz 2004; 99:335-339.

10. Picollo MI, Vassena C, Orihuela PS, Barrios S, Zaidemberg M, Zerba E. High resistence to pyrrethroid insecticides associated with ineffective field treatments in Triatoma infestans (Hemiptera: Reduviidade) from Northern Argentina. J Med Entomol 2005; 42:637-642.

11. Sfara V, Zerba EM, Algozagay RA. Toxicity of pyrethroids and repellency of diethyltoluamide in two deltamethrin-resistant colonies of Triatoma infestans Klug, 1834 (Hemiptera: Reduviidae). Mem Inst Oswaldo Cruz 2006; 101:89-94.

12. Reyes M, Angulo VM, Sandoval CM. Efecto tóxico de B-cipermetrina, deltametrina y fenitrotión en cepas de Triatoma dimidiate (Letreille, 1811) y Triatoma maculate (Erichson, 1848) (Hemiptera, Reduviidae). Biomedica 2007; 27:75-82.

13. Santo Orihuela PL, Vassena CV, Zerba EN, Picollo MI. Relative contribution of monooxygenase and esterase to pyrethroid resistance in Triatoma infestans (Hemiptera: Reduviidae) from Argentina and Bolivia. J Med Entomol 2008; 45:298-306.

14. Toloza AC, Germano M, Cueto GM, Vassena C, Zerba E, Picollo MI. Differencial patterns of insecticide resistance in eggs and first instar of Triatoma infestans (Hemiptera: Reduviidae) from Argentina and Bolivia. J Med Entomol 2008; 45:421-426.

15. Sonoda IV, Pessoa GCD, Cortez MR, Dias JC, Romanha AJ, Diotaiuti L. Susceptibility of Triatoma infestans to deltamethrin in Rio Grande do Sul, Brazil. Mem Inst Oswaldo Cruz 2009; 104:668-670.

16. Alarico AG, Romero N, Hernández L, Catalá S, Gorla D. Residual effect of a micro-encapsulated formulation of organophosphates and piriproxifen on the mortality of deltamethrin resistant Triatoma infestans populations in rural houses of the Bolivian Chaco region. Mem Inst Oswaldo Cruz 2010; 105:752-756.

17. Germano MD, Roca Acevedo G, Mougabure Cueto GA, Toloza AC, Vassena CV, Picollo MI. New findings of insecticide resistance in Triatoma infestans (Heteroptera: Reduviidae) from the Gran Chaco. J Med Entomol 2010; 47:1077-1081. 
18. Rojas de Arias A, Lehane MJ, Schofield CJ, Fournet A. Comparative evaluation of pyrethroid insecticide formulations against Triatoma infestans (Klug): residual efficacy on four substrates. Mem Inst Oswaldo Cruz 2003; 98:975-980.

19. Santo Orihuela PL, Picollo MI. Contribuition of general esterases to pyrethroid resistant Triatoma infestans (Hemiptera: Reduviidae) from Argentina and Bolivia. Acta Toxicol Argentina 2011; 19:32-40.

20. Fabro J, Sterkel M, Capriotti N, Mougabure-Cueto G, Germano $\mathrm{M}$, Rivera-Pomar R, et al. Identification of a point of mutation associated with pyrethroid resistance in the para-type sodium channel of Triatoma infestans, a vector of Chagas disease. Infect Genet Evol 2012; 12:487-491.

21. Capriotti N, Mougabure-Cueto G, Rivera-Pomar R, Ons S. L925I Mutation in the Para-type soddium channel is associated with pyrethroid resistance in Triatoma infestans from the Gran Chaco Region. PLoS Negl Trop Dis 2014; 8:e2659.

22. World Health Organization (WHO). Control of Chagas disease. Second report of the WHO Expert Committee. Buenos Aires: WHO Techinical Report Series; 2006.

23. Organización Panamericana de la Salud (PAHO). II Reunion técnica latinoamericana de monitoreo de resistência a insecticidas em triatominos vectores de Chagas, OPS. Panamá: PAHO; 2005.

24. Pessoa GCD. Monitoramento da suscetibilidade ao piretróide deltametrina em populações de Triatoma sordida Stål, 1859 (Hemiptera: Reduviidae). 2008. 95 p. (Masters Thesis) Centro de Pesquisas René Rachou, Fundação Oswaldo Cruz, Belo Horizonte, 2008.

25. World Health Organization (WHO). Taller sobre la evaluación de efecto insecticida sobre triatominos. Workshop on the insecticide effect evaluation in triatominos. Acta Toxicol Argentina 1994; 2:29-33.

26. Finney DJ. Probit analysis. Ann Appl Biol 1971; 36:187-195.

27. Cercere MC, Vazquez-Prokopec GM, Gürtler RE, Kitron U. Spatio-temporal analysis of reinfestation by Triatoma infestans (Hemiptera: Reduviidae) following insecticide spraying in a rural community in a Northweastern Argentina. Am Trop Med Hyg 2004; 71:803-810.

28. Marcet PL, Lehmann T, Groner G, Gurtler RE, Kitron U, Dotson EM. Identification and characterization of microsatellite markers in the Chagas disease vector Triatoma infestans (Heteroptera: Reduviidae). Infect Genet Evol 2006; 6:32-37.

29. Gürtler RE, Kitron U, Cecere MC, Segura EL, Cohen JE. Sustainable vector control and management of Chagas disease in the Gran Chaco, Argentina. Proc Natl Acad Sci USA 2007; 104:16194-16199.

30. Gürtler R. Sustainability of vector control strategies in the Gran Chaco Region: current challenges and possible approaches. Mem Inst Oswaldo Cruz 2009; 104:52-59.

31. Lardeux F, Depickère $S$, Cuchon $S$, Chaves T. Insecticide resistance of Triatoma infestans (Hemiptera, Reduviidae) vector of Chagas disease in Bolivia. Tropic Medic Intern Health 2010; 15:1037-1048.

32. Roca-Acevedo G, Mougabure Cueto GA, Germano M, Orihuela PS, Cortez MR, Noireau F, et al. Susceptibility of sylvatic Triatoma infestans from Andeans Valleys of Bolivia to deltamethrin and fipronil. J Med Entomol 2011; 48:828-835.

33. Depickère $S$, Buitrago $R$, Siñani E, Baune $M$, Monje $M$, Lopez $\mathrm{R}$, et al. Susceptibility and resistance to deltamethrin of wild and domestic populations of Triatoma infestans (Reduviidae: Triatominae) in Bolivia: new discoveries. Mem Inst Oswaldo Cruz 2012; 107:1042-1047.
34. Pinchin R, Fanara DM, Oliveira Filho AM. A village scale trail of Pirimiphos-methyl (OMS 1424), wettable power and slow-release formulations, in comparison with $\mathrm{HCH}$ for the controle of Triatoma infestans in Brazil. World Health Org 1984; VBC/82.840. 8 p.

35. Silveira AC, Rezende DF. Epidemiologia e controle da transmissão vetorial da doença de Chagas no Brasil. Rev Soc Bras Med Trop 1994; 27:11-22.

36. Perez de Rosas AR, Segura EL, García BA. Microssatellites analysis of genetic structure in natural Triatoma infestans (Hemiptera: Reduviidae) populations from Argentina: its implication in assessing the effectieness of Chagas disease vector control programmes. Mol Ecol 2007; 16:1401-1412.

37. Perez de Rosas AR, Segura EL, Fichera L, Garcia BA. Macrogeographic and microgeographic genetic structure of the Chagas disease vector Triatoma infestans (Hemiptera: Reduviidade) from Catamarca, Argentina. Genetica 2008; 133:247-260.

38. Toloza AC, Germano M, Cueto GM, Vassena C, Zerba E, Picollo MI. Differencial patterns of insecticide resistance in eggs and first instar of Triatoma infestans (Hemiptera: Reduviidae) from Argentina and Bolivia. J Med Entomol 2008; 45:421-426.

39. Mouganbure Cueto G, Zerba E, Picollo MI. Biological effect of 1-dodecanol in teneral and post-teneral Rhodnius prolixus and Triatoma infestans (Hemiptera: Reduviidae). Mem Inst Oswaldo Cruz 2005; 100:59-61.

40. Germano M, Picollo MI, Mouganbure-Cueto GS. Microgeographical study of insecticide resistance in Triatoma infestans from Argentina. Acta Tropica 2013; 128:561-565.

41. Pessoa GC, Dias LS, Diotaiuti L. Deltamethrin pyrethroid susceptibility characterization of Triatoma sordida Stål, 1859 (Hemiptera: Reduviidae) populations in the Northern Region of Minas Gerais, Brazil. Rev Soc Bras Med Trop 2014; 47:426-429.

42. Amelotti I, Catalá SS, Gorla DE. Experimental evaluation of insecticidal paints against Triatoma infestans (Hemiptera: Reduviidae), under natural climtic conditions. Parasit Vectors 2009; 2:30.

43. Pessoa GCD. Perfil da suscetibilidade a deltametrina em populações de Triatoma sordida (Hemiptera: Reduviidae) do Estado de Minas Gerais procedentes de áreas com infestação persistente. 2012. 179 p. (Doctors Thesis) Universidade Federal de Minas Gerais, Belo Horizonte, 2012.

44. Rojas de Arias A, Lehane MJ, Schofield CJ, Maldonado M. Pyrethroid insecticide evaluation on different house structure in a Chagas disease endemic area of the Paraguayan Chaco. Mem Inst Oswaldo Cruz 2004; 99:6657-6662.

45. Gurtler RE, Canale DM, Spillmann C, Striolo R, Salomón OD, Blanco S, et al. Effectiveness of residual spraying of peridomestic ecotopes with deltamethrin and permethrin on Triatoma infestans in rural western Argentina: a district wide randomized trial. Bull World Health Organ 2004; 82:196-205.

46. Diotaiuti L, Pinto CT. Suscetibilidade biológica do Triatoma sordida e Triatoma infestans a deltametrina e lambdacyalotrina em condições de campo. Rev Soc Bras Med Trop 1991; 24:151-155.

47. Porcasi X, Catala SS, Hellac H, Scavuzzo MC, Gorla DE. Infestation of rural houses by Triatoma infestans (Hemiptera: Reduviidae) in Southern area of Gran Chaco in Argentina. J Med Entomol 2006; 43:1060-1067. 